\title{
Gas exchange and water relations of evergreen and deciduous tropical savanna trees
}

\author{
G. Goldstein ${ }^{1}$, F. Rada 2 , P. Rundel ${ }^{1}$, A. Azocar ${ }^{2}$ and A. Orozco 2 \\ 1 Laboratory of Biomedical and Environmental Sciences, University of California Los Angeles, 900 \\ Veteran Ave., Los Angeles, CA 90024, U.S.A., and \\ 2 Departamento de Biologia, Facultad de Ciencias, Universidad de Los Andes, Merida, Venezuela
}

\section{Introduction}

Many neotropical savannas with pronounced wet/dry seasonality and welldrained soils are characterized by the presence of both evergreen and deciduous trees. The evergreen species grow as isolated individuals in the oligotrophic soils which predominate, while the deciduous species form small forest 'islands' located on patches of richer soil (Sarmiento, 1984). The trees in these forest islands are mostly drought deciduous, dropping their leaves at the onset of the dry season. In contrast to the more pliant foliage of the deciduous species, evergreen trees tend to have scleromorphic leaves. An additional structural difference is that evergreen species have relatively large root systems allowing them access to soil water throughout the rainless period (Medina, 1982; Sarmiento et al., 1985).

The purpose of this study was to investigate gas exchange characteristics, water relations and vascular hydraulic properties of 2 evergreen and 2 drought deciduous tree species. In addition, carbon isotope ratios of leaf tissue were measured to fur- ther evaluate water use efficiency. Our main hypotheses are that: 1) the vascular system of the evergreen trees is more efficient than the vascular system of the deciduous species for water transport; 2) the structural basis for the high efficiency in water transport of the evergreen species is more related to the cross-sectional area of the conducting tissue per surface area of supplied leaves (Huber values) than to intrinsic properties of the vascular system, such as large vessels; 3 ) despite the fact that the leaves of the evergreen plants are more scleromorphic and longer lived, its $\mathrm{CO}_{2}$ assimilation rates are as high or even higher, than the photosynthetic rates of deciduous trees; and 4) water and nitrogen use efficiencies are similar between the 2 groups of species. Some of these hypotheses contradict current notions concerning leaf life span and physiological behavior of the plant species.

\section{Materials and Methods}

Two evergreen and 2 deciduous woody species were studied in the Venezuelan llanos $(200 \mathrm{~m}$ elev., $9^{\circ} 37^{\prime} \mathrm{N}$ and $70^{\circ} 12^{\prime} \mathrm{W}$ ). Curatella america- 
na and Byrsonima crassifolia, the 2 evergreen species, initiate leaf renewal during the middle of the dry season, when the old leaves start to senesce. The average leaf life span is approximately 14 mo. Leaf longevity of the 2 drought deciduous species, Genipa caruto and Cochlospermum vitifolium is shorter. Leaf production starts with the onset of the rainy season, and leaves last for about 8-9 mo, at which time water is no longer available in the upper part of the soil profile.

A portable system was used to measure gas exchange in the field (LCA-2 system). Gas exchange calculations are according to von Caemmerer and Farquhar (1981). Leaf water potential was measured with a pressure chamber. Hydraulic properties were estimated using methods outlined in Zimmermann (1978) and Goldstein et al. (1987). Sap flow velocity was measured with a heat pulse apparatus. Carbon isotope ratios of leaf tissues are reported in $\delta$ units relative to PDB standard.

\section{Results and Discussion}

Evergreen species generally exhibited higher rates of water loss than deciduous species (Fig. 1). The rate of water loss was determined both by extrapolations of the porometer measurements on an area basis and by calculation from heat pulse measurements. Both estimates of volumetric water flux tend to agree. Despite differences in transpiration rates, minimum water potentials were not significantly different between the 2 groups of species suggesting a higher efficiency of water transport in the evergreen species.

Physiological estimates of hydraulic properties in terminal stem sections of several branches support the hypothesis that resistances to water flow in the liquid phase were significantly smaller in the evergreen than in deciduous savanna trees (Table I). Leaf-specific conductivities (LSCS - hydraulic conductivity per leaf surface area supplied) were higher in the evergreen plants. Terminal branches were used to compare the hydraulic conductivity among species because smaller branches tend to be less efficient in water transportation and represent, therefore, the hydraulic constriction or bottleneck for water movement in the plant.

Table I summarizes information on the xylem anatomy, the ratio between the xylem transverse section and the total surface area of the supported leaves and the sap flux density predicted by Poiseuille's law for ideal capillaries. Regression analysis for $L S C$ versus all the anatomical and morphological variables indicates that the Huber value is the best predictor of $L S C$ $\left(r^{2}=0.87\right)$. An important intrinsic characteristic of the water flow system, such as the mean vessel diameter for example,

Table I. Anatomical and physiological characteristicsa of the water transport system of 2 evergreen and 2 deciduous savanna species.

\begin{tabular}{llllll}
\hline Species & $\begin{array}{l}\mathrm{LSC} \\
\left(\mu l \cdot \mathrm{h}^{-1} \cdot \mathrm{cm}^{-2}\right)\end{array}$ & $\mathrm{N}$ & $\begin{array}{l}\mathrm{r} \\
(\mu \mathrm{m})\end{array}$ & $\begin{array}{l}\mathrm{q}^{\mathrm{H}-\mathrm{P}} \\
\left(\mathrm{mm} \cdot \mathrm{s}^{-1}\right)\end{array}$ & $\begin{array}{l}\text { Alleaf area } \\
\left(\mathrm{cm}^{2} / \mathrm{cm}^{2} \times 10^{-4}\right)\end{array}$ \\
\hline C. americana & 0.47 & 18 & 34.9 & 11.0 & 3.07 \\
B. crassifolia & 1.47 & 45 & 25.1 & 6.9 & 4.50 \\
C. vitifolium & 0.10 & 11 & 55.6 & 41.0 & 0.79 \\
G. caruto & 0.20 & 43 & 20.8 & 3.2 & 1.06 \\
\hline
\end{tabular}

aLSC is the leaf specific conductivity per $\mathrm{cm}^{2}$ of projected area of leaf supplied, $N$ is the number of xylem elements per $\mathrm{mm}^{2}$ in stem cross-sections, $r$ is the mean radius of the xylem elements, $q^{H-P}$ is the sap flux density calculated according to the Hagen-Poiseuille law (stem lengths of $10 \mathrm{~cm}$ ) and $\Delta P$ of $0.1 \mathrm{MPa}$ were used in calculations), and $A$ leaf area is the ratio between the cross-sectional area of conducting tissue and total leaf area (Huber value). 


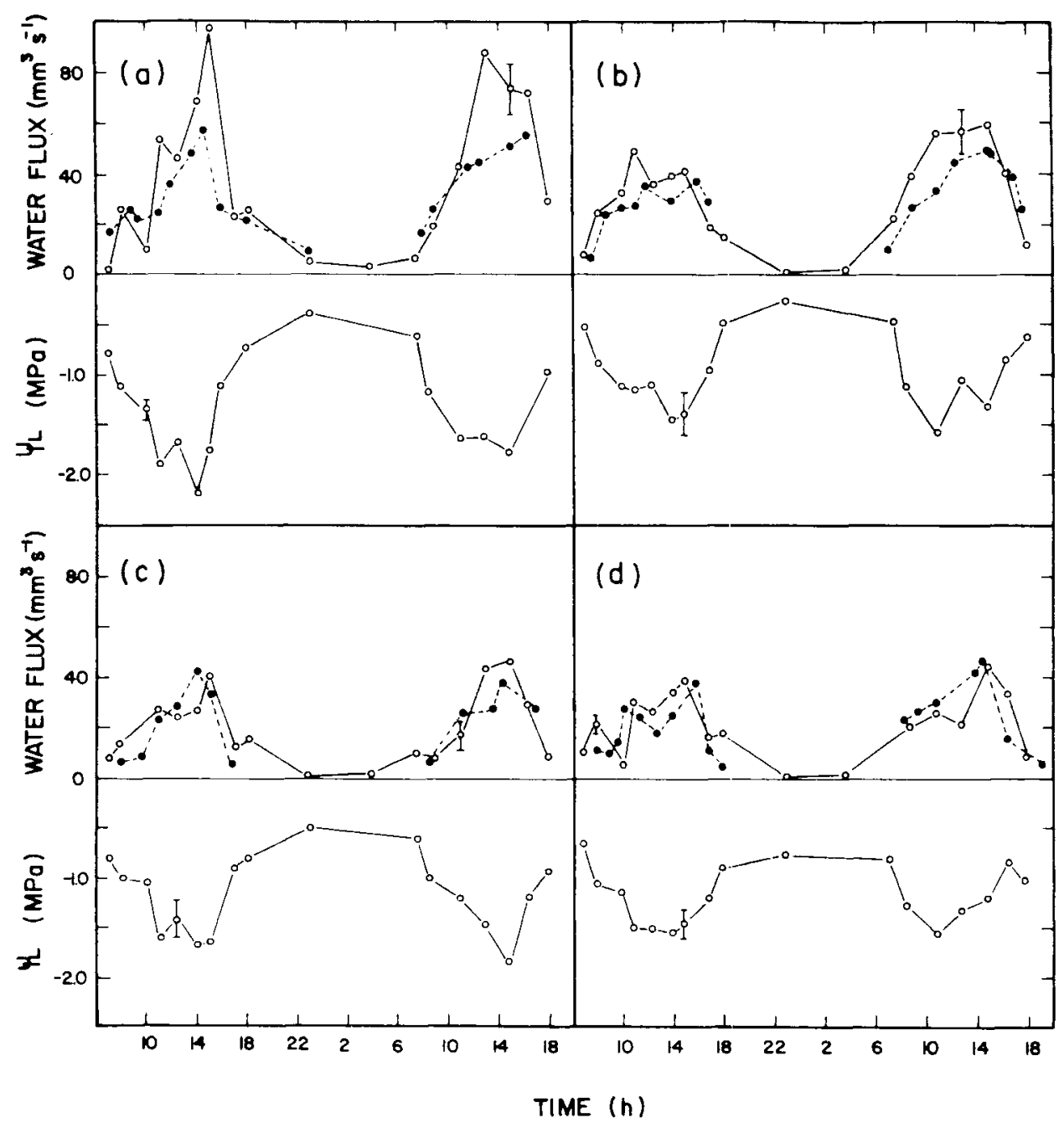

Fig. 1. Daily courses of transpiration (O) extrapolated on an area basis from the porometer measurements, volumetric sap flow through the stem (O) calculated from heat pulse measurements and leaf water potentials, during 2 high evaporative demand days for (a) C. americana, (b) B. crassifolia, (c) C. vitifolium and (d) G. caruto. Bars indicate the largest standard error above and below the mean for each daily course. (From Goldstein et al., 1987.)

was not significantly correlated with L.SC. It appears that the increased hydraulic efficiency of evergreen tropical savanna species is a consequence of relatively low total leaf surface area compared to the amount of vascular tissue, rather than the consequence of wider and more efficient conducting vessels.

Photosynthetic rates and instantaneous water use efficiencies were monitored in 


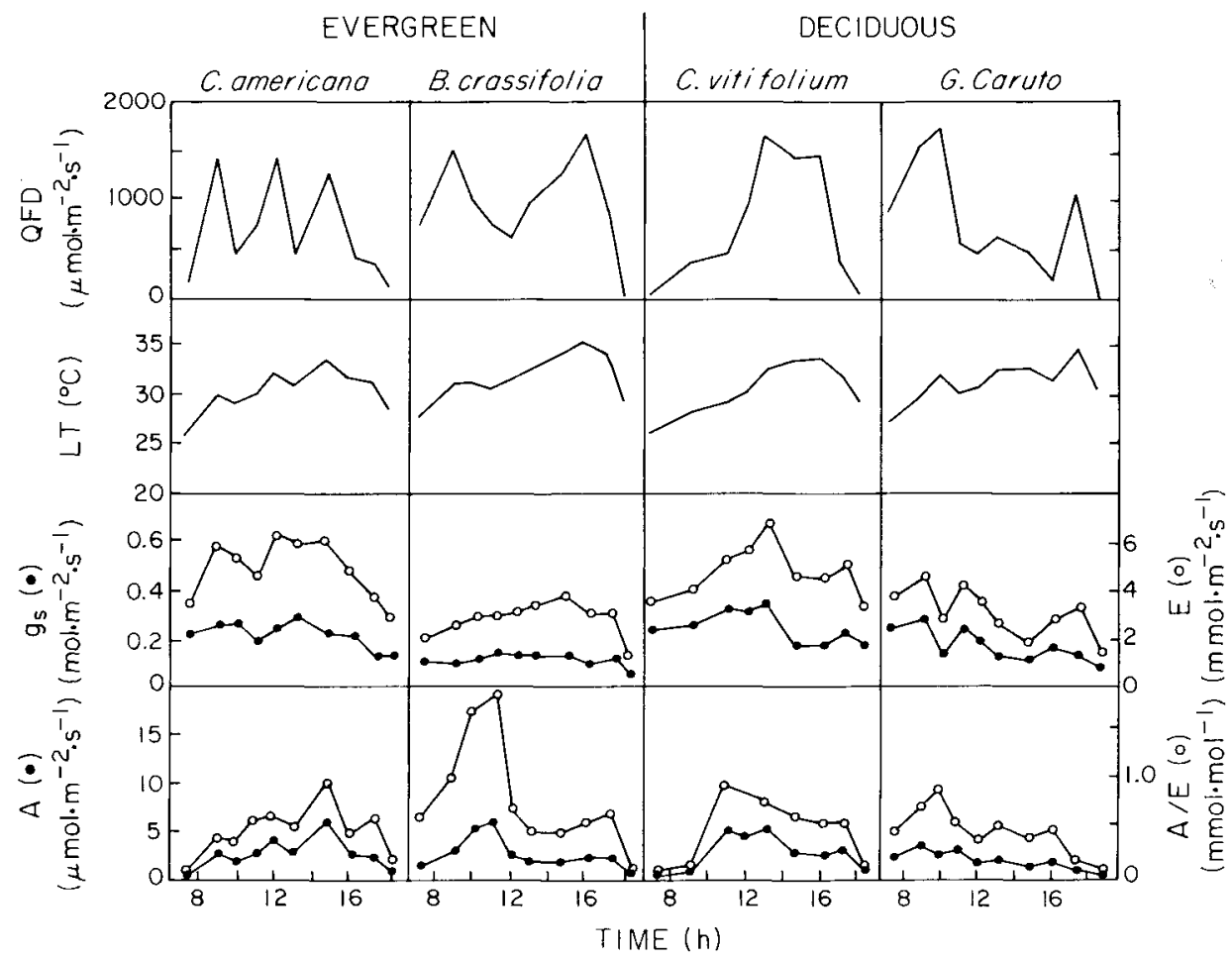

Fig. 2. Representative daily courses of photosynthetic active radiation (QFD), leaf temperature ( $L T$ ), stomatal conductance $\left(g_{\mathrm{s}}\right)$, transpiration rate $(E)$, net assimilation $(A)$ and water use efficiency $(A / E)$, for 2 evergreen and 2 deciduous savanna tree species.

the field during the wet season, when both groups of species support active leaves. Neither the photosynthetic capacity nor the water use efficiency of the deciduous species was higher relative to the evergreen species (Fig. 2); integration of gas exchange measurements during the course of the day generally suggests that the photosynthetic rates of the evergreen species tend to be slightly higher (data not shown). We have expressed gas exchange measurements on an area-base because light interception and gas exchange with the atmosphere are areabased phenomena (however, see Field and Mooney, 1986). Large differences in specific leaf weight (leaf mass to area ratio) between deciduous and evergreen plants result in larger differences in photosynthetic rates expressed on a weight basis. Carbon isotope ratios of leaf tissue were measured to further evaluate water use efficiency. Table II shows that the $\delta^{13} \mathrm{C}$ values of several evergreen and deciduous savanna trees, including the previous 4 species $\delta^{13} \mathrm{C}$ values were in the range of -27 to $-31 \%$, and that there were no significant differences between deciduous and evergreen trees. Furthermore, there were no significant differences in 
Table II. Mean values of $\delta^{13} \mathrm{C}$ and water use efficiency $(A E)$ for the evergreen and deciduous tree species.

\begin{tabular}{llll}
\hline Leaf persistence & Species & $\begin{array}{l}\delta^{13 \mathrm{C}} \\
(\%)\end{array}$ & $\begin{array}{l}\mathrm{AVE} \\
(\mathrm{mmol} \cdot \mathrm{mol}-1)\end{array}$ \\
\hline Evergreen & $\begin{array}{l}\text { Byrsonima crassifolia } \\
\text { Curatella americana }\end{array}$ & -30.23 & 1.47 \\
& $\begin{array}{l}\text { Palicourea rigida } \\
\text { Bowdichia virgilioides }\end{array}$ & -29.11 & 1.01 \\
& Casearia sylvestris & -26.74 & 0.76 \\
& Cochlospermum vitifolium & -30.32 & - \\
Deciduous & -28.17 & 1.40 \\
& Genipa caruto & -29.57 & 1.06 \\
& Godmania macrocarpa & -28.57 & 1.06 \\
& & & 0.68 \\
\hline
\end{tabular}

instantaneous water use efficiencies (WUE) between evergreen and deciduous trees. The small differences between WUE as estimated by gas exchange and as estimated by the relative amount of carbon stable isotopes can be attributed to differences in nighttime respiration rates and differences in timing of leaf construction (dry season for the evergreen trees versus wet season for the deciduous trees).

The 2 evergreen species have more efficient systems for water transport than do the 2 deciduous woody species. In the high evaporative demand savanna environment, water transport efficiency is advantageous because it permits maintenance of high stomatal conductance without turgor loss, particularly during the dry season when evaporative demand is higher. It is possible that relatively high conductances may be critical for the maintenance of a favorable carbon and nutrient balance in the evergreen species. Compared to deciduous trees, evergreen trees have a much higher maintenance cost due to the presence of an extensive root system and scleromorphic leaves. An increased leaf life span increases the time period for photosynthesis. In this regard, the evergreen strategy can compensate for higher maintenance costs; however, it appears that increased life span does not amortize additional maintenance costs if photosynthetic rates of evergreen species are low.

\section{Acknowledgments}

This study was supported in part by a CONICIT grant no. S1-1588 and by an NSF grant (BSR-86-15575). We are grateful to C. Swift for her comments on the manuscript.

\section{References}

Field C. \& Mooney H.A. (1986) The photosyn thesis-nitrogen relationship in wild plants. In: On the Economy of Plant Form and Function (Givnish T.J., ed.), Cambridge University Press, Cambridge, pp. 25-55

Goldstein G., Rada F. \& Catalan A. (1987) Water transport efficiency in stems of evergreen and deciduous savanna trees. In: Proceedings of the International Conference on Measurement of Soil and Plant Water Status, Vol. 2. Plants. Utah State University, pp. 267-274 
Medina E. (1982) Physiological ecology of neotropical savanna plants. In: Ecology of Tropical Savannas, Ecological Studies 42. (Huntley B.J. \& Walker B.H., eds.), Springer-Verlag, Berlin, pp. 308-355

Sarmiento G. (1984) In: The Ecology of Neo tropical Savannas. Harvard University Press, Cambridge, pp. 235

Sarmiento G., Goldstein G. \& Meinzer F. (1985) Adaptative strategies of woody spe- cies in neotropical savannas. Biol. Rev. 60, 315-355

von Caemmerer S. \& Farquhar G.D. (1981) Some relationships between the biochemistry of photosynthesis and the gas exchange of leaves. Planta 153, 376-387

Zimmermann M.H. (1978) Hydraulic architecture of some diffuse-porous trees. Can. J. Bot. $56,2286-2295$ 